\title{
Jual Beli Hak Atas Tanah Berdasarkan Akta Kuasa Menjual Notariil
}

\author{
Dwi Hartiningsih \\ Fakultas Hukum Universitas Islam Indonesia Yogyakarta Indonesia \\ Jln. Taman Siswa No. 158, Yogyakarta Indonesia \\ dwiamel22@gmail.com
}

\begin{abstract}
This research examines the sale and purchase of land rights based on the notarial power of attorney to sell in Magelang Regency. The problems formulated are first, what has been the consideration of the Magelang Regency National Land Agency (BPN) to limit the validity of the notarial deed stating capacity to selling; and second, how is the settlement made by PPAT in relation to the sale and purchase of land based on the notarial power of attorney to sell which is limited by BPN. This is a normative-empiric research supported by information obtained from the respondents and analysed using statutory and conceptual approach with qualitative descriptive method. Hence in this study, primary and secondary legal materials were used. This research concludes that first, BPN's consideration in limiting the validity period of the power of attorney to sell power deed has no legal basis but only based on the precautionary principle, in implementing this principle, however, BPN has not carried out any socialization steps to the public in general and notaries in particular, so that future similar problems may be solved quickly and accurately and does not deviate from the existing norms and/or regulations. Second, the steps taken by PPAT in resolving this issue include approaching and reviewing regulations while finding the best and most effective solution in resolving problems with the $B P N$ of Magelang Regency.
\end{abstract}

Key Words: Land rights; notarial power of attorney to sell; sale and purchase

\begin{abstract}
Abstrak
Penelitian ini meneliti tentang jual beli hak atas tanah berdasarkan akta kuasa menjual notariil di Kabupaten Magelang. Permasalahan yang dirumuskan adalah pertama, apa yang menjadi pertimbangan Kantor Badan Pertanahan Nasional (BPN) Kabupaten Magelang membatasi masa berlaku akta kuasa menjual secara notarial; dan kedua, bagaimana penyelesaian yang dilakukan oleh PPAT terkait dengan jual beli atas tanah berdasarkan kuasa menjual notariil yang dibatasi oleh BPN. Jenis penelitian ini adalah normatif empiris yang didukung dengan keterangan yang diambil dari responden dengan menggunakan pendekatan perundangan-undangan dan pendekatan konseptual serta menganalisanya dengan menggunakan metode deskriptif kualitatif. Dalam penelitian ini digunakan bahan hukum primer dan sekunder. Penelitian ini menyimpulkan bahwa pertama bahwa dasar pertimbangan BPN dalam membatasi masa berlakunya akta kuasa jual tidak ada dasar hukumnya, hanya berdasarkan prinsip kehati-hatian, namun dalam melakukan prinsip tersebut BPN belum melakukan langkah sosialisasi kepada masyarakat umumnya dan Notaris pada khususnya, sehingga apabila terjadi masalah yang sama dapat diselesaikan dengan cepat dan akurat serta tidak menyimpang dari norma dan atau peraturan-peraturan yang ada. Kedua, langkah yang ditempuh oleh PPAT dalam menyelesaikan hal tersebut antara lain dengan pendekatan, telaah peraturan dan mencari solusi terbaik dan tepat guna dalam menyelesaikan persoalan dengan BPN Kabupaten Magelang.
\end{abstract}

Kata-kata kunci: Jual beli, hak atas tanah, kuasa menjual notarial 


\section{Pendahuluan}

Tidak dapat dipungkiri bahwa semua aktivitas kehidupan dilakukan di atas tanah, segala sesuatu berada dan berhubungan dengan tanah, dengan mana negara berperan serta berwenang mengatur dan menyelenggarakan peruntukkan, penggunaan, persediaan dan pemeliharaan tanah dan pengadaan tanah untuk memenuhi terlaksananya setiap kegiatan manusia. Tanah merupakan permukaan bumi anugerah dari Tuhan Yang Maha Esa tempat tinggal manusia dan para makhluk lainnya. Keberadaan akan tanah harus dijaga dan dipelihara dengan baik mengingat tanah memiliki peranan yang sangat penting bagi kelangsungan hidup semua makhluk di bumi ini, khususnya manusia. Pentingnya arti tanah tersebutsebagai salah satu alasan bagi masyarakat untuk memiliki dan menempatinya. Seiring bertambahnya kebutuhan akan tanah, namun jumlah tanah yang tidak bertambah tentu dapat mengakibatkan permasalahan, maka dari itu masyarakat telah mengenal pengaturan tentang tanah bahkan sejak hanya pengaturan melalui hukum adat atau belum dengan undang-undang.

Di Indonesia pengaturan utama tentang tanah ada pada Undang-Undang Nomor 5 Tahun 1960 tentang Pokok-Pokok Agraria (UUPA). Tentang apa yang disebut hukum tanah atau hukum agraria itu dapatlah dengan secara singkat dikatakan bahwa hukum tanah adalah hukum yang mengatur hubungan antara orang dan tanah dengan orang lain. ${ }^{1}$ Jadi merupakan perlindungan kepentingan orang terhadap orang lain mengenai tanah. Hukum ada memang karena manusia, disini banyak terjadi interaksi manusia untuk memenuhi kebutuhan akan tanah. Disini hukum tanah muncul untuk mengaturnya.

Sebagai bukti pentingnya pendaftaran tanah untuk memperoleh alat bukti hak atas tanah, pemerintah telah mengeluarkan Peraturan Pemerintah Nomor 10 Tahun 1961 yang sudah diganti dengan Peraturan Pemerintah Nomor 24 Tahun 1997 tentang Pendaftaran Tanah pada 8 Juli 1997. Peraturan pemerintah tersebut merupakan peraturan pelaksanaan pendaftaran tanah seperti yang diharapkan dalam UUPA. Sehingga pada setiap perubahan yang terjadi mengenai kepemilikan hak atas tanah harus didaftarkan dan wajib mendaftarkan hak tersebut. Obyek pendaftaran tanah meliputi;

a. Bidang-bidang tanah yang dipunyai dengan hak milik, hak guna usaha, hak guna bangunan dan hak pakai;

b. Tanah hak pengelolaan;

c. Tanah wakaf; 

d. Hak milik atas satuan rumah susun;
e. Hak tanggungan;
f. Tanah negara. ${ }^{2}$

Hak Milik (HM) menjadi satu-satunya hak primer dengan kedudukan terkuat jika dibandingkan dengan hak-hak lainnya sesuai ketentuan Pasal 20 ayat (1) UUPA yang menyatakan: "Hak milik adalah hak turun-temurun, terkuat dan terpenuh yang dapat dipunyai orang atas tanah dengan mengingat ketentuan dalam pasal 6".

Terbitnya sertipikat atas tanah menjadi salah satu jaminan kepastian hukum hak milik baik perorangan maupun sekelompok orang yang tergabung dalam sebuah entitas atas sejumlah tanah tertentu di wilayah tertentu setelah melalui mekanisme untuk menjamin kepastian hak-hak atas tanah (recht kadaster) dimana kadaster sendiri berarti suatu daftar yang melukiskan semua persil tanah yang ada dalam suatu daerah berdasarkan pemetaan dan pengukuran yang cermat. ${ }^{3}$ Undang-undang serta peraturan yang mengatur mengenai penguasaan dan tata kelola tanah, hak atas tanah serta pengukuran dan pendaftaran tanah sebaiknya memiliki aspek perencanaan sesuai skala prioritas yang disesuaikan dengan pola pemenuhan kebutuhan masyarakat yang paling mendasar tanpa mengabaikan pentingnya menyertakan aspek penunjang pertumbuhan ekonomi secara dinamis sehingga fokus utama perancangan jaminan kepastian yuridis berkaitan dengan hak kepemilikan atas tanah mampu memberikan keadilan yang sebaik-baiknya. Oleh karena itu, seluruh lapisan masyarakat memiliki jaminan perlindungan hukum yang semestinya guna memperoleh dan memanfaatkan tanah sebagai pelaksanaan kebutuhan esensial manusia. ${ }^{4}$

Pada prinsipnya, pendaftaran tanah sebagaimana dijelaskan dalam Pasal 19 UUPA memiliki tujuan memberikan kepastian hukum yang meliputi objek tanah, hak dan subjek serta ketertiban administrasi pertanahan baik bagi pemilik maupun pihak-pihak yang menguasai tanah tersebut, yang dibuktikan dengan kepemilikan sertipikat tanah atas nama yang bersangkutan sebagai alat pembuktian yang kuat dan sah.

Sesuai buku II Kitab Undang-Undang Hukum Perdata Pasal 506 ayat (1), tanah masuk dalam kategori benda tidak bergerak (benda tetap) sehingga proses jual belinya pun berbeda dengan proses jual beli benda bergerak seperti kendaraan. Perbuatan hukum yaitu proses jual beli yang berakibat pengalihan

\footnotetext{
2Pasal 9 ayat (1) Peraturan Pemerintah Nomor 24 Tahun 1997 tentang Pendaftaran Tanah

${ }^{3}$ Mariam Darus Badrulzaman, Beberapa Masalah Hukum dalam Perjanjian Kredit Bank Dengan Jaminan Hypotheek Serta Hambatan-hambatannya Dalam Praktek. Di Medan, Citra Aditya Bakti, Jakarta, 1991, hlm. 97.

${ }^{4}$ Maria S. W. Sumardjono, Kebijakan Pertanahan: Antara Regulasi dan Implementasi, Penerbit Buku Kompas, Jakarta, 2009, hlm. 20.
} 
hak atas kepemilikan tanah harus selalu diikuti dengan pembuatan akta autentik yang diperlukan sebagaimana telah diatur secara khusus mengenai hal tersebut. Akta autentik yang dimaksud dibuat oleh pejabat umum yang berwenang yaitu Pejabat Pembuat Akta Tanah (PPAT), dimana dalam hal-hal tertentu melibatkan akta Notaris. Ketentuan mengenai PPAT dapat ditemukan pada Peraturan Pemerintah Nomor 24 Tahun 1997 tentang Pendaftaran Tanah yang mengatur jabatan serta tugas PPAT; Peraturan Pemerintah Nomor 37 Tahun 1998 tentang Jabatan Pejabat Pembuat Akta Tanah dengan pelaksanaan tugas diatur lebih lanjut dalam Peraturan Menteri Negara Agraria/Kepala Badan Pertanahan Nasional Nomor 4 Tahun 1998. Aspek yuridis mengenai jabatan notaris dapat ditemukan pada Undang-undang Nomor 30 Tahun 2004 tentang Jabatan Notaris yang disempurnakan dengan Undang-undang Nomor 2 Tahun 2014 tentang Perubahan Atas Undang-undang Nomor 30 Tahun 2004 tentang Jabatan Notaris. Proses pemindahan hak kepemilikan atas tanah dari pihak penjual kepada pihak pembeli telah diatur dalam Peraturan Pemerintah Nomor 24 Tahun 1997 tentang Pendaftaran Tanah dan Peraturan Pemerintah Nomor 37 Tahun 1998 tentang Peraturan Jabatan Pejabat Pembuat Akta Tanah (PPAT). Pengalihan hak kepemilikan atas tanah harus dilakukan di hadapat pejabat yang berwenang dalam hal ini adalah PPAT, yang daerah kerjanya meliputi wilayah lokasi tanah yang diperjual belikan. Pasal 4 ayat (1) Peraturan Pemerintah Nomor 37 Tahun 1998 menyatakan: "PPAT hanya berwenang membuat akta mengenai hak atas tanah atau Hak Milik Atas Satuan Rumah Susun yang terletak di daerah kerjanya".

Berdasarkan peristiwa tersebut, PPAT berhak dan wajib menyusun akta perubahan kepemilikan (balik nama) berupa Akta Jual Beli (AJB) yang bersifat autentik, dimana bentuk dan isinya telah ditetapkan oleh peraturan perundangundangan yang berlaku sehingga PPAT hanya mengisi blanko akta yang telah tersedia. Adapun terdapat prasyarat yang harus dipenuhi sebelum PPAT dapat mengesahkan proses jual beli tanah dengan ditandai keluarnya AJB oleh pejabat yang bersangkutan. Prasyarat tersebut diantaranya adalah hak atas tanah yang diperjual belikan merupakan hak atas tanah yang sah dimiliki oleh penjual yang dibuktikan dengan sertipikat tanah atau tanda bukti sah lainnya berkaitan dengan status kepemilikan atau penguasaan atas tanah. Selain itu, tanah yang diperjual belikan tidak berada dalam sengketa dengan pihak lain. Prasyarat berkaitan dengan subjek jual beli adalah adanya pembeli yang mensyaratkan bahwa hak atas tanah yang dibeli memiliki sertipikat sebagai bukti kepemilikan yang sah atas tanah sehingga tanah tanpa sertipikat ataupun tanda bukti sah kepemilikan lainnya belum bisa dibayar lunas oleh pembeli. 
Terpenuhinya prasyarat tersebut memungkinkan pelaksanaan penandatanganan AJB sebagai proses pemindah tanganan status kepemilikan dan penguasaan hak atas tanah dapat dilakukan di hadapan PPAT sesuai ketentuan peraturan perundang-undangan yang berlaku. Namun sebaliknya, PPAT berhak menolak membuatkan AJB sebagai konsekuensi tidak terpenuhinya prasyarat perjanjian jual beli yang dimaksud. Kondisi ini tentu sangat tidak menguntungkan bagi salah satu pihak penjual maupun pembeli ataupun keduaduanya. Pihak penjual terpaksa menunda keinginannya untuk segera memperoleh keuntungan sebagai manifestasi nilai ekonomis atas tanah yang dimilikinya, sementara pihak pembeli juga harus menunda keinginannya untuk segera memiliki dan memanfaatkan hak kepemilikan atas tanah yang hendak dibeli guna kepentingan lebih lanjut.

Saat ini banyak masyarakat melakukan transaksi jual beli tanah akan tetapi tidak serta merta dapat dibuatkan akta jual beli yang penandatanganannya dilakukan di hadapan Pejabat Pembuat Akta Tanah. Hal tersebut misalkan saja dikarenakan penjual tidak dapat menunjukkan asli sertipikat, yang nantinya sertipikat tersebut akan dilakukan pengecekan keasliannya di Kantor Badan Pertanahan setempat. Apabila sertipikat asli tersebut tidak dapat ditunjukkannya, maka PPAT dapat menolak pembuatan akta jual belinya sebagaimana tertera dalam Pasal 39 ayat (1) huruf a PP Nomor 24 Tahun 1997. Sertipikat asli tidak dapat ditunjukkan kepada PPAT karena masih dalam proses pengurusan sertipikat di Kantor Pertanahan, misalkan saja karena:

a. Tanah yang menjadi objek jual beli tersebut masih berstatus tanah warisan dan sertipikat masih dalam proses balik nama waris di Kantor Pertanahan;

b. Adanya proses pemecahan sertipikat dikarenakan yang dibeli hanya sebagian dari tanah tersebut;

c. Adanya konversi tanah, atau pendaftaran tanah untuk pertama kalinya oleh pihak pemilik;

d. Adanya roya.

Solusi untuk mengatasi permasalahan tersebut ditempuh dengan dibuatnya pengikatan jual beli antara pihak penjual dan pihak pembeli. Pengikatan jual beli adalah perjanjian antara pihak penjual dan pihak pembeli sebelum dilaksanakannya jual beli dikarenakan adanya unsur-unsur yang harus dipenuhi untuk jual beli tersebut antara lain sertipikat hak atas tanah yang belum ada karena masih dalam proses, atau belum terjadinya pelunasan harga atau pajak- 
pajak yang dikenakan terhadap jual beli hak atas tanah belum dapat dibayar baik oleh pihak penjual ataupun pihak pembeli. ${ }^{5}$

Implementasi pengikatan jual beli tersebut adalah dikeluarkannya akta Perjanjian Perikatan Jual Beli (PPJB). Akta PPJB merupakan ikatan awal antara penjual dan pembeli yang bersifat di bawah tangan (akta non autentik) sehingga tidak mengikat tanah sebagai objek jual beli atau dengan kata lain tidak menyebabkan beralihnya hak kepemilikan atas tanah dari pihak penjual kepada pihak pembeli. Di dalam akta PPJB biasanya disebutkan bahwa pihak penjual sepakat untuk menjual tanahnya kepada pihak pembeli yang telah disepakati, namun prosesnya belum dapat dilaksanakan karena sebab tertentu yang kemudian dituangkan dalam akta PPJB sebagai prasyarat yang harus dipenuhi oleh para pihak guna terwujudnya AJB. Oleh karena itu, PPJB melahirkan hak dan kewajiban untuk memenuhi prestasi dan kontra prestasi antara para pihak yang mengikatkan diri sebagaimana ketentuan-ketentuan yang disepakati dan dituangkan dalam perjanjian. Pengaturan lebih lanjut yang disebutkan dalam PPJB adalah berkaitan dengan tindakan selanjutnya yang dapat ditempuh apabila persyaratan tentang proses jual beli hak kepemilikan atas tanah telah dipenuhi. Clausa ini dimasukkan jika dalam situasi dan kondisi tertentu prasyarat jual beli telah dipenuhi dan proses penandatanganan AJB dapat dilangsungkan, pihak penjual tidak mungkin hadir karena pertimbangan jarak yang jauh ataupun sakit dan lain sebagainya, pihak pembeli diberikan kuasa untuk menghadap sendiri kepada PPAT guna melaksanakan penanda tanganan AJB atas nama sendiri serta atas nama penjual. Pemberian kuasa diatur secara spesifik pada Bab XVI, buku III Kitab Undang-undang Hukum Perdata dimana Pasal 1792 menyatakan: "Pemberian kuasa ialah suatu persetujuan yang berisikan pemberian kekuasaan kepada orang lain yang menerimanya untuk melaksanakan sesuatu atas nama orang yang memberikan kuasa".

Lebih lanjut, Pasal 1793 Kitab Undang-undang Hukum Perdata menyatakan: "Kuasa dapat diberikan dan diterima dengan suatu akta umum, dengan suatu surat di bawah tangan bahkan dengan sepucuk surat ataupun dengan lisan. Penerimaan suatu kuasa dapat pula terjadi secara diam-diam dan disimpulkan dari pelaksanaan kuasa itu oleh yang diberi kuasa". Pemberian kuasa dalam hal implementasi PPJB merupakan bentuk kuasa tertulis yang dibuat oleh pejabat notaris (Kuasa Notariil) atau yang lazim disebut akta kuasa sebagai hasil

5R. Subekti, Hukum Perjanjian, Bina Cipta, Bandung, 1987, hlm. 75. 
penyusunan oleh dan atas buah pikiran dari pejabat notaris itu sendiri, atau menyesuaikan dengan draft standar yang telah umum digunakan.

Sebelum menyusun akta kuasa, notaris wajib menanyakan keperluan pembuatannya dengan disertai penyerahan data kependudukan yang masih berlaku dari para pihak berupa kartu tanda penduduk (KTP) pemberi dan penerima kuasa, KTP suami atau istri pemberi kuasa, kartu keluarga (KK) pemberi kuasa ataupun surat nikah. Hal tersebut ditempuh berkaitan dengan kepentingan legalitas serta persyaratan tuntutan peraturan perundang-undangan yang berlaku dimana untuk melepaskan suatu hak kebendaan, seseorang harus mendapatkan persetujuan dari pasangannya. Notaris juga wajib menanyakan syarat-syarat khusus lainnya yang hendak dicantumkan oleh para pihak dalam akta kuasa. ${ }^{6}$

Berdasarkan sifat perjanjiannya ${ }^{7}$, pemberian kuasa dapat bersifat umum dan khusus. Pemberian kuasa umum adalah pemberian kuasa yang dirumuskan dengan kata-kata umum yang biasanya hanya meliputi perbuatan-perbuatan pengurusan. Pemberian kuasa khusus adalah pemberian kuasa yang berkaitan dengan satu kepentingan tertentu. Sehingga untuk melakukan perbuatanperbuatan tertentu diperlukan pemberian kuasa khusus yang menyebutkan perbuatan yang harus dilakukan. Pasal 1796 Kitab Undang-Undang Hukum Perdata menyatakan: "Pemberian kuasa yang dirumuskan secara umum hanya meliputi tindakan-tindakan yang menyangkut pengurusan. Untuk memindahtangankan barang atau meletakkan hipotek di atasnya, untuk membuat suatu perdamaian, ataupun melakukan tindakan lain yang hanya dapat dilakukan oleh seorang pemilik, diperlukan suatu pemberian kuasa dengan katakata yang tegas".

Dalam prakteknya, pemberian kuasa ini seringkali mengalami penyimpangan. Penyimpangan yang dimaksud adalah pada batasan yang ditetapkan dalam Pasal 1796 Kitab Undang-Undang Hukum Perdata tidak selalu diindahkan, demikian juga halnya dengan batasan yang diberikan pada Pasal 1813 Kitab Undang-Undang Hukum Perdata mengenai waktu berakhirnya pemberian kuasa juga seringkali dilanggar. Kondisi inilah yang sering dianalogikan dengan istilah kuasa mutlak.

Berdasarkan uraian dan hal-hal yang telah dikemukakan, maka menarik untuk mengkaji lebih dalam terkait berbagai permasalahan-permasalahan tersebut dalam sebuah penelitian yang penulis angkat tema permasalahan

\footnotetext{
${ }^{6}$ Wicaksono, Panduan Lengkeap Membuat Surat-Surat Kuasa, Visimedia, Jakarta, 2009, hlm. 1.

${ }^{7}$ R. Subekti, Aneka Perjanjian, PT. Citra Aditya Bakti, Bandung, 1995, hlm. 143.
} 
mengenai “Jual Beli Hak Atas Tanah Berdasarkan Akta Kuasa Menjual Notariil Di Kabupaten Magelang".

\section{Rumusan Masalah}

Berdasarkan uraian di atas, maka penulis merumuskan permasalahan sebagai berikut: Pertama, apa yang menjadi pertimbangan Kantor Badan Pertanahan Nasional (BPN) Kabupaten Magelang membatasi masa berlaku akta kuasa menjual secara notariil? Kedua, bagaimana penyelesaian yang dilakukan oleh PPAT terkait dengan jual beli atas tanah berdasarkan kuasa menjual notariil yang dibatasi oleh BPN?

\section{Tujuan Penelitian}

Adapun yang menjadi tujuan dilakukannya penelitian adalah sebagai berikut: Pertama, untuk menganalisis pertimbangan Kantor Badan Pertanahan Nasional (BPN) Kabupaten Magelang membatasi masa berlaku akta kuasa menjual secara notarial. Kedua, untuk menganalisis cara penyelesaian yang dilakukan oleh PPAT terkait dengan jual beli atas tanah berdasarkan kuasa menjual notariil yang dibatasi oleh BPN

\section{Metode Penelitian}

Objek penelitian adalah sesuatu yang dapat memberikan data atau informasi penelitian, yang menjadi objek penelitian penulis adalah jual beli hak atas tanah berdasarkan akta kuasa menjual notarial di Kabupaten Magelang. Subjek dalam penelitian ini adalah responden. Responden merupakan seseorang yang dapat memberikan jawaban atas pertanyaan yang diajukan oleh peneliti serta terkait langsung dengan data yang dibutuhkan ${ }^{8}$. Responden dalam penelitian ini ialah 5 orang Notaris/PPAT aktif di Kabupaten Magelang dan 1 orang dari Kantor Badan Pertanahan Kabupaten Magelang.

Data penelitian atau bahan hukum adalah informasi atau keterangan yang benar mengenai objek penelitian. Dalam data penelitian empiris dapat berupa data primer dan sekunder. Penelitian lapangan merupakan penelitian yang bertujuan untuk mengumpulkan data primer secara langsung pada lokasi penelitian. penelitian lapangan dilakukan dengan cara wawancara secara langsung dengan pihak-pihak terkait mengenai hal-hal yang berkaitan dengan penelitian dan menggunakan alat berupa kerangka atau pedoman wawancara

8S. Nasution, Metode Reaseach (Penelitian Ilmiah), PT. Bumi Aksara, Jakarta, 2006, hlm. 52. 
yang telah dibuat sebelumnya. ${ }^{9}$ Sumber data primer dalam penelitian ini adalah Notaris dan PPAT serta Kantor Badan Pertanahan Nasional Kabupaten Magelang. Data sekunder yaitu data yang diperoleh dari dokumen-dokumen resmi, bukubuku yang berhubungan dengan objek penelitian, hasil penelitian dalam bentuk laporan, skripsi, tesis, disertasi dan peraturan perundang-undangan. ${ }^{10}$ Pengumpulan data sekunder dilakukan dengan cara membaca, mempelajari, serta menganalisis peraturan perundang-undangan, buku-buku, literature serta artikel yang terkait dengan objek penelitian.

Bahan hukum yang digunakan dalam penelitian ini meliputi: a. Bahan hukum primer adalah bahan hukum yang mempunyai otoritas (autoritatif) ${ }^{11}$ atau bahanbahan hukum yang mengikat, berasal dari ketentuan perundang-undangan yang berlaku dan berhubungan dengan permasalahan yang dibahas. Bahan hukum primer disini adalah : 1) Kitab Undang-Undang Hukum Perdata (KUHPerdata) terjemahan Subekti dan Tjitrosudibio; 2) Undang-Undang Nomor 30 Tahun 2004 tentang Jabatan Notaris (Lembaran Negara Republik Indonesia Tahun 2004 Nomor 117, tambahan Lembar Negara Republik Indonesia Nomor 4432); 3) Undang-Undang Nomor 2 Tahun 2014 tentang Perubahan Atas Undang-Undang Nomor 30 Tahun 2004 tentang Jabatan Notaris (Lembaran Negara Republik Indonesia Tahun 2014 Nomor 3); 4) Undang-Undang Nomor 5 Tahun 1960 tentang Pokok-pokok Agraria; 5) Peraturan Pemerintah Nomor 24 Tahun 1997 tentang Pendaftaran Tanah. b. Bahan hukum sekunder adalah semua publikasi tentang hukum yang merupakan dokumen yang tidak resmi ${ }^{12}$ antara lain ialah buku, literatur, dokumen-dokumen resmi dan laporan hasil penelitian yang relevan. Bahan hukum sekunder yang dipergunakan dalam penelitian ini adalah: 1) berbagai kepustakaan mengenai lembaga kenotariatan; 2) berbagai kepustakaan mengenai akta kuasa jual notarial; c. Bahan hukum tersier terdiri dari bahan-bahan yang akan memberikan petunjuk atau penjelasan terhadap bahan hukum primer dan bahan hukum sekunder yaitu Kamus Besar Bahasa Indonesia.

Pengumpulan data merupakan hal yang sangat erat hubungannya dengan sumber data, dikarenakan melalui pengumpulan data akan memperoleh daya yang diperlukan oleh penulis yang selanjutnya dianalisis sesuai dengan yang diharapkan.

Adapun dalam penelitian ini, pengumpulan data dilakukan dengan cara sebagai berikut:

'Suharsimi Arikunto, Prosedur Penelitian Suatu Pendekatan Praktek, Edisi Revisi IV, PT. Rineka Cipta, Jakarta, 1998, hlm. 137.

${ }^{10}$ Ibid., hlm. 106

${ }^{11}$ Ibid., hlm. 47

${ }^{12}$ Ibid., hlm. 54 


\section{Data primer}

Data primer adalah data-data yang diperoleh langsung dari lapangan melalui proses wawancara terhadap narasumber yang dianggap mengetahui segala informasi yang diperlukan dalam penelitian, berupa pengalaman praktik dan pendapat subjek penelitian tentang segala sesuatu yang berkaitan dengan Jual Beli Hak Atas Tanah Berdasarkan Akta Kuasa Menjual Notariil di Kabupaten Magelang.

Adapun sistem wawancara yang dilakukan dalam penelitian ini adalah wawancara bebas terpimpin, artinya terlebih dahulu penulis mempersiapkan daftar pertanyaan sebagai pedoman, tetapi dimungkinkan juga adanya variasi pertanyaan yang disesuaikan dengan situasi pada saat wawancara dilakukan. ${ }^{13}$

\section{Data sekunder}

Data sekunder adalah data-data yang diperoleh melalui studi kepustakaan dengan cara studi dokumen.

\section{Pendekatan penelitian}

Ada beberapa pendekatan yang dilakukan dalam penelitian hukum ini yaitu sebagai berikut: a. Pendekatan Undang-Undang (Statute Appoach); Penelitian normatif empiris tentunya harus menggunakan pendekatan perundangundangan, karena yang akan diteliti adalah berbagai aturan hukum yang menjadi fokus tema sentral dalam penelitian. b. Pendekatan Konseptual (Conseptual Approach); Pendekatan konseptual dari penelitian ini berasal dari pandanganpandangan dan doktrin-doktrin yang berkembang. c. Pendekatan Kasus (Case Approach); Pendekatan kasus atau case approach dalam penelitian ini bertujuan untuk mempelajari mengenai penerapan-penerapan maupun norma-norma terkait dengan kaidah hukum yang dilakukan dalam praktik hukum.

\section{Analisis penelitian}

Penulis dalam menganalisis hasil penelitian menggunakan langkah-langkah sebagai berikut: mengelompokkan data sesuai dengan permasalahan, memadukan kelompok-kelompok yang satu dengan lainnya dalam setiap permasalahan dan memberikan makna dari apa yang dianalisis. Data primer dan data sekunder yang telah terkumpul dianalisis dengan metode kualitatif.

Metode kualitatif merupakan tata cara penelitian yang mengelompokkan dan menyeleksi data yang diperoleh dari penelitian lapangan, kemudian dihubungkan dengan teori-teori yang diperoleh dari studi kepustakaan, sehinga

13 Soetrisno Hadi, Metodologi Reasearch Jilid III, Yayasan Penerbit Fakultas Hukum Psikologi UGM, Yogyakarta, tt, hlm. 26. 
menghasilkan data deskriptif berupa jawaban atas permasalahan penelitian. ${ }^{14}$ Metode analisis data yang digunakan dalam penelitian ini adalah metode analisis kualitatif, yaitu data yang diperoleh disusun secara sistematis kemudian dianalisis secara kualitatif agar dapat diperoleh kejelasan masalah yang akan dibahas. Analisis data kualitatif adalah suatu cara penelitian yang menghasilkan data deskriftip analisis, yaitu yang dinyatakan oleh responden secara tertulis atau lisan dan perilakunya nyata, diteliti dan dipelajari secara utuh.

\section{Hasil Penelitian dan Pembahasan}

Pertimbangan Badan Pertanahan Nasional membatasi masa berlaku akta kuasa menjual secara notariil menurut beberapa responden yang berhasil penulis wawancarai diantaranya adalah Bapak Mardhanto Bapak Pangat Suwarto, S.H., mewakili sebagai berikut:

Menurut Mardhanto, selaku Kepala Sub Seksi Pendaftaran Hak Tanah Badan Pertanahan Nasional Kabupaten Magelang, BPN tetap memberlakukan masa berlaku akta kuasa jual notariil dengan melampirkan fotocopy KTP dan KK terbaru, dengan pertimbangan BPN khawatir pemberi kuasa sudah meninggal, kuasa itu telah dicabut, kawatir kuasa itu dibatalkan, oleh karena itu BPN tetap mengharuskan untuk pemberkasan dilengkapi dengan KTP dan KK terbaru.

Menurut Pangat Suwarto,15 sebagai Analis Hukum Pertanahan di Badan Pertanahan Nasional Kabupaten Magelang untuk pelayanan kepada masyarakat, BPN mengacu kepada Peraturan Kepala Badan Pertanahan Nasional Nomor 1 Tahun 20100 tentang Standar Pelayanan dan Pengaturan Pelayanan khususnya Pasal 3 dan Pasal 4. Pasal 3 menyebutkan bahwa tujuan peraturan ini adalah untuk mewujudkan kepastian hukum, keterbukaan dan akuntabilitas pelayanan publik sedangkan Pasal 4 menyebutkan ruang lingkup pengaturan peraturan ini meliputi: a.kelompok dan jenis pelayanan; b.persyaratan; c.biaya; d.waktu; e.prosedur ; dan f.pelaporan. Berdasarkan Pasal 4 huruf b terkait persyaratan, BPN menerapkan prinsip kehati-hatian, terkait kuasa jual memang tidak ada peraturan yang mengatur masa berlaku akta kuasa jual, tetapi BPN khawatir apabila tidak dilengkapi dengan KTP terbaru kuasa itu bisa saja sudah dicabut, atau si pemberi kuasa itu telah meninggal dunia dan lain-lain. Jadi pada prinsipnya BPN melakukan kegiatan administrasi sesuai dengan standar operasional prosedur yang telah ditentukan, baik ditentukan oleh peraturan yang ada ataupun dengan kebijakan Kepala Kantor.

\footnotetext{
${ }^{14}$ Soerjono Soekanto, Pengantar Penelitian Hukum, UI Press, Jakarta 2010, hlm. 32.

15 Wawancara dengan Pangat Suwarto, Analis Hukum Pertanahan Kantor Badan Pertanahan Nasional Kabupaten Magelang pada 25 Agustus 2020
} 
Menurut Muhammad Nizam Fanani, ${ }^{16}$ berdasarkan PMNA No. 3 Tahun 1997, tidak ada aturan yang mengatur tentang surat kuasa, didalam PP 24 terdapat larangan tentang kuasa mutlak untuk dasar peralihan hak, hanya itu saja. Yang menyebut kuasa jual itu hanya mengarah kepada tidak diperbolehkannya atau diperkenankannya memakai dasar kuasa mutlak sebagai dasar peralihan hak. Jadi secara normatif tidak ada peraturan yang mengatur tentang batas waktunya, yang mengatur tentang kuasa jual terdapat di KUHPerdata Pasal 1813 yaitu: "pemberian kuasa berakhir; dengan ditariknya kembali kuasanya si kuasa, dengan pemberitahuan penghentian kuasanya oleh si kuasa; dengan meninggalnya, pengampuannya atau pailitnya si pemberi kuasa maupun si kuasa, dengan perkawinannya si perempuan yang memberikan atau menerima kuasa", sepanjang itu tidak ada peristiwa atau perbuatan hokum kuasa itu masih tetap berlaku. Permasalahan kenapa di BPN memberlakukan kuasa ada batas waktunya itu sebetulnya salah kaprah, hanya mereka itu ingin mengetahui apakah kuasa itu masih berlaku atau tidak dengan asumsi apabila masih 1 tahun apakah si pemberi kuasa masih hidup, belum pernah dicabut dan lain sebagainya tetapi tidak relevan juga, itu hanya hokum adat saja, apabila BPN tetap mengharuskan KTP si pemberi kuasa itu masih berlaku, itu sesuatu hal yang muskhil, KTP dan KK yang masih berlaku itu sesuai dengan PP 24 tentang persyaratan pendaftaran tanah itu adalah para pihak (pihak yang mengajukan), yang mengajukan siapa? Subjeknya adalah si penerima kuasa itu yang masih harus berlaku. BPN mengharuskan KTP dan KK yang masih berlaku jadi harus dibedakan mereka [unya asumsi jika sipemberi kuasa itu sudah mati, maka kuasanya gugur, sebetulnya mengada-ngada, karena mereka tidak punya dasar hokum yang jelas. Kalau BPN tetap bersikukuh itu keliru, itulah perlunya pendekatan, belajar bersama untuk lebih mengetahui dasar hukumnya.

Menurut Ladrang Kunto Anuraga, yang dimaksud dengan pemberian kuasa sesuai dengan KUHPerdata Pasal 1792 adalah suatu persetujuan dengan mana seseorang memberikan kekuasaan kepada orang lain yang menerimanya untuk atas namanya menyelenggarakan suatu urusan ${ }^{17}$. Pada Pasal 1793 disebutkan kuasa dapat diberikan dan diterima dalam suatu akta umum, dalam suatu tulisan dibawah tangan, bahkan dalam sepucuk surat ataupun dengan lisan. Terkait BPN membuat suatu kebijakan membatasa masa berlakunya akta kuasa jual harus dilengkapi dengan fotocopy KTP dan KK terbaru itu merupakan tafsiran 08.18

16 Wawancara dengan Notaris Muhammad Nizam Fanani di Kabupaten Magelang pada 24 Agustus 2020,

${ }^{17}$ Hasil wawancara dengan Bapak Ladang Kunto Anuraga di Kabupaten Magelang pada 8 Agustus 2020, 10.51 
tersendiri tentang kuasa, padahal di KUHPerdata Pasal 1813 terkait cara berakhirnya pemberian kuasa sudah secara nyata disebutkan tidak terdapat klausula bahwa kuasa itu berakhir dengan identitas yang terbaru, pasal 1813 KUHPerdata menyebutkan kapan masa berlakunya kuasa itu berakhir itu sepanjang tidak ditarik, sepanjang tidak meninggal dan lain-lain, kalau BPN itu beralasan KTP dan KKnya harus baru, itu sudah masa lalu, padahal sekarang berlaku seumur hidup, kuasa menjual itu akta notariil dan dikalahkan dengan legalisir foto copy KTP dan KK, maka sama saja akta notariil yang dibuat dikalahkan dengan fotocopyan atau legalisiran.

Menurut Ibu Virgina Rapar, ${ }^{18}$ terkait pembatasan masa berlaku akta kuasa jual notariil tidak ditemukan aturan ataupun undang-undang yang mengatur tentang masa berlakunya kuasa jual, selama praktik memang belum menemui kuasa jual dibatasi masa berlakunya oleh BPN, BPN kemungkinan menerapkan prinsip kehatihatian dalam menjalankan tugas administrasinya, jangan sampai akta kuasa notariil itu sebenarnya si pemberi kuasa sudah mencabut atau malah sudah meninggal dunia tetapi tetap diproses untuk peralihan hak. Terkait tentang kuasa sebenarnya bisa dilihat di KUHPerdata Pasal 1792 sampai dengan 1819, diantaranya tentang sifat pemberian kuasa, kewajiban-kewajiban penerima kuasa, kewajiban-kewajiban pemberi kuasa serta macam-macam cara berakhirnya pemberian kuasa.

Menurut Dwi Kimtoro, ${ }^{19}$ terkait pembatasan masa berlaku kuasa jual notariil oleh di BPN kurang mendasar, karena tidak disebutkan dasar aturannya, di KUHPerdata khususnya pasal 1813 tentang masa berakhirnya kuasa hanya disebutkan ditarik kembali kuasa, pemberitahuan penghentian oleh pemberi kuasa dan dengan meninggalnya pemberi kuasa. Kemungkinan besar BPN melakukan itu untuk berjaga-jaga jangan sampai ada masalah dikemudian hari, karena kalau terjadi sengketa BPN akan menjadi turut tergugat di Pengadilan.

Menurut Funnyarifki, ${ }^{20}$ kalau BPN berpedoman seperti itu, mungkin untuk memastikan saja, jangan sampai peralihan haknya dikemudian hari terjadi masalah, dengan tidak mengesampingkan peraturannya, BPN berhak untuk menentukan mana yang bisa diterima atau dikembalikan kepada si penerima kuasa. Kalau BPN memberlakukan KTP dan KK itu harus masih berlaku pada saat ini seharusnya sudah tidak terjadi lagi, karena sekarang sudah berbentuk EKTP, walaupun di E-KTP tercantum ada masa berlakunya, tapi berdasarkan peraturan Menteri Dalam Negeri, bahwa E-KTP itu berlaku seumur hidup, harus ada benang merahnya bagaimana caranya kita mencari E-KTP untuk

${ }^{18}$ Hasil wawancara dengan Ibu Virgina Rapar di Kabupaten Magelang pada 13 Agustus 2020, 13.46 ${ }^{19}$ Hasil wawancara dengan Bapak Dwi Kimtoro di Kabupaten Magelang pada 24 Agustus 2020, 14.10

${ }^{20}$ Hasil wawancara dengan Bapak Funnyarifki di Kabupaten Magelang pada 25 Agustus 2020, 14.40 
meminimalisir resiko yang akan terjadi. Sebuah pengalaman ketika dimintai klien pengembang untuk meneruskan proses dari notaris lain yang bertahun-tahun tidak jalan, akhirnya kita menelusuri bagaimana cara untuk menyelesaikan masalah yang dihadapi oleh klien, prosesnya memang panjang sekitar 1 tahunan, setelah mendapatkan kita benahi administrasi yang belum lengkap apa saja, dinamika bidang pertanahan memang sangat dinamis, kadang pejabat yang menjabat punya kebijakan satu sama lain dengan pejabat yang lain.

Secara umum, dalam prinsipnya surat kuasa tunduk pada hukum yang diatur dalam Bab XVI, Buku III KUH Perdata, sedangkan aturan khususnya jelas diatur dan tunduk pada ketentuan hukum acara yang digariskan dalam HIR dan RBG. Apabila suatu perjanjian mempunyai alasan sendiri (tidak tergantung pada perjanjian lain), maka perjanjian seperti ini merupakan perjanjian pokok, dan sebaliknya apabila suatu perjanjian yang alasan dibuatnya bergantung pada adanya perjanjian lain, maka perjanjian ini merupakan perjanjian bantuan atau disebut Pactum de contrahendo ${ }^{21}$.

Agar dapat memahami pengertian kuasa secara umum, kita dapat merujuk ke dalam Pasal 1792 KUH Perdata, yang bunyinya: Pemberian kuasa adalah suatu persetujuan dengan mana seorang memberikan kekuasaan kepada seorang lain, yang menerimanya, untuk dan atas namanya menyelenggarakan suatu urusan. Pasal 1792 maupun Pasal 1793 ayat (1) KUH Perdata menyatakan pemberian kuasa selain didasarkan atas persetujuan kedua belah pihak, dapat dituangkan dalam bentuk akta autentik atau di bawah tangan maupun dengan lisan. Namun demikian tanpa mengurangi penjelasan di atas, berdasarkan Pasal 1793 a (2) KUH Perdata, penerimaan kuasa dapat terjadi secara diam-diam dan hal itu dapat disimpulkan dari pelaksanaan kuasa itu oleh pemberi kuasa. Akan tetapi, cara diam-diam ini, tidak dapat diterapkan dalam pemberian kuasa khusus.

Namun perlu dipahami bahwa pemberian kuasa dapat berakhir, berakhirnya pemberian kuasa umumnya dikarenakan telah adanya pencabutan atau penarikan kembali kuasa oleh pemberi kuasa, mengandung prinsip bahwa kuasa dapat ditarik sewaktu-waktu bila dikehendaki. Bahkan Pasal 1814 KUHPerdata memberikan kemungkinan penarikan atau pencabutan kembali kuasa secara paksa, bila penerima kuasa tidak mengembalikan secara sukarela maka dapat dipaksa dengan peran hakim. Berakhirnya Surat Kuasa diatur dalam Pasal 1813-1819 BW, begitu juga halnya surat kuasa menjual yang pada prinsipnya masuk ke dalam skema pembagian surat kuasa.

21 Agus Pandoman, Perbuatan Hukum Tertentu dalam Sistem Hukum Agraria di Indonesia, PT. Raga Utama Kreasi, Jakarta, tt, hlm. 28-29 
Menurut Agus Pandaoman mengenai cara berakhirnya pemberian kuasa, dalam Pactum de contrahendo, ditentukan oleh perjanjian pokoknya, dimana perjanjian pokok memegang peran utama dalam menentukan proses lavering-nya, sehingga ketentuan tersebut berakibat hukum yang timbul dalam Pasal $1813 \mathrm{~s} / \mathrm{d}$ pasa; 1819 Kitab Undang-Undang Hukum Perdata dapat diberlakukan sepanjang perjanjian pokoknya sudah dilaksanakan. ${ }^{22}$

Menurut Muhammad Nizam Fanani, ${ }^{23}$ penyelesaian yang dilakukan oleh PPAT perlunya adanya pendekatan, sharing bersama-sama terkait masalah yang dihadapi, sekarang yang berurusan dengan objeknya siapa, yang penting ada solusi-solusi yang bisa dilakukan, contohnya ada surat keterangan bahwa si pemberi kuasa masih hidup, tidak mencabut kuasa tersebut dan lain-lain, sehingga proses peralihan haknya bisa berjalan.

Menurut Ladrang Kunto Anuraga, ${ }^{24}$ BPN itu terkadang memang mencari enak sendiri, membuat pagar supaya aman, mencari aman itu wajib, namun kadang BPN tidak mau belajar dengan peraturan perundangan, penyelesaian yang dilakukan kita hadapkan dengan pasal atau peraturan perundangan yang berlaku, kalau mereka tetap menolak, BPN harus mempunyai dasar penolakannya. Kadang menjadi dilema, bagi saya selaku praktisi sepanjang kita masih bisa ngemong, kita mengamini keanehan BPN, kita coba mendatangi pihak yang memberi kuasa, tetapi kalau si pemberi kuasa itu, biasanya kalau BPN itu kalau sudah pakai rumus "POKOKE" nah itu yang kadang membuat tugas kita sebagai praktisi Notaris kesulitan.

Menurut Virgina Rapar,25 yang dilakukan oleh PPAT adalah dengan pendekatan dengan pihak BPN, apakah ada solusi yang bisa disepakati bersama antara BPN dan Notaris, sehingga kedepannya jika terjadi masalah yang sama, Notaris mempunyai pedoman ataupun petunjuk teknis yang benar untuk memenuhi proses administrasi di BPN.

Menurut Dwi Kimtoro, ${ }^{26}$ jika terjadi hal semacam itu, Notaris mempunyak hak bertanya dan hak menjawab, hak bertanya dilakukan kepada BPN atau perwakilannya, solusi apa yang paling tepat untuk menyelesaikan masalah tersebut, sehingga tidak terjadi miskomunikasi antara BPN dengan Notaris

Menurut Funnyarifki,27 langkah yang dapat dilakukan oleh PPAT adalah mencari benang merah penyelesaian masalah tersebut dengan melakukan

\footnotetext{
${ }^{22}$ Ibid., hlm. 40-41

${ }^{23}$ Wawancara dengan Notaris Muhammad Nizam Fanani di Kabupaten Magelang pada 24 Agustus 2020, 08.18

${ }^{24}$ Hasil wawancara dengan Bapak Ladang Kunto Anuraga di Kabupaten Magelang pada 8 Agustus 2020, 10.51

${ }^{25}$ Hasil wawancara dengan Ibu Virgina Rapar di Kabupaten Magelang pada 13 Agustus 2020, 13.46

${ }^{26}$ Hasil wawancara dengan Bapak Dwi Kimtoro di Kabupaten Magelang pada 24 Agustus 2020, 14.10

${ }^{27}$ Hasil wawancara dengan Bapak Funnyarifki di Kabupaten Magelang pada 25 Agustus 2020, 14.40
} 
komunikasi terlebih dahulu dengan pihak yang berwenang dalam hal ini BPN, untuk memastikan langkah yang tepat, karena kadang kebijak pejabat yang satu dengan pejabat yang lainnya tidak sama, sehingga kesepakatan yang sudah ada bisa berubah karena kebijakan pejabat yang baru.

\section{Penutup}

Berdasarkan pada uraian pembahasan terhadap kedua permasalahan yang diteliti dalam penelitian ini, maka kesimpulan yang dapat dikemukakan adalah sebagai berikut. Pertama, bahwa dasar pertimbangan BPN dalam membatasi masa berlakunya akta kuasa jual tidak ada dasar hukumnya, hanya berdasarkan prinsip kehati-hatian, namun dalam melakukan prinsip tersebut BPN belum melakukan langkah sosialisasi kepada masyarakat umumnya dan Notaris pada khususnya, sehingga apabila terjadi masalah yang sama dapat diselesaikan dengan cepat dan akurat serta tidak menyimpang dari norma dan atau peraturanperaturan yang ada. Kedua, langkah yang ditempuh oleh PPAT dalam menyelesaikan hal tersebut antara lain dengan pendekatan, telaah peraturan dan mencari solusi terbaik dan tepat guna dalam menyelesaikan persoalan dengan BPN Kabupaten Magelang

Adapun saran-saran yang dapat diberikan berdasarkan kesimpulan di atas sebagai berikut:

1. BPN dalam melaksanakan tupoksinya seharusnya tetap berpegang teguh pada peraturan dan atau perundangan yang ada, tidak membuat tafsiran sendiri terkait hal-hal yang sudah diatur dalam undang-undang, terkait teknis yang bersifat administratif, sebaiknya BPN melakukan langkah-langkah persuasive seperti sosialisasi teknis pelayanan pendaftaran peralihan hak.

2. Pengurus Daerah Ikatan Notaris Indonesia Kabupaten Magelang sebaiknya pro aktif jika ada persoalan-persoalan teknis yang dihadapi para Notaris di Kabupaten Magelang, sehingga tidak hanya Notaris secara personal tetapi juga organisasi juga ikut berperan aktif dalam menyelesaikan persoalan-persoalan yang dihadapi para Notaris dalam menjalankan profesinya.

\section{Daftar Pustaka}

\section{Buku}

Arikunto, Suharsimi, Prosedur Penelitian Suatu Pendekatan Praktek, Edisi Revisi IV, PT. Rineka Cipta, Jakarta, 1998. 
Badrulzaman, Mariam Darus, Beberapa Masalah Hukum dalam Perjanjian Kredit Bank Dengan Jaminan Hypotheek Serta Hambatan-hambatannya Dalam Praktek Di Medan, Citra Aditya Bakti, Jakarta, 1991.

Hadi, Soetrisno, Metodologi Reasearch Jilid III, Yayasan Penerbit Fakultas Hukum Psikologi UGM, Yogyakarta, tt.

Mertokusumo, Sudikno, Perundang-undangan Agraria Indonesia, Liberty, Yogyakarta, 2011.

Pandoman, Agus, Perbuatan Hukum Tertentu dalam Sistem Hukum Agraria di Indonesia, PT. Raga Utama Kreasi, Jakarta, tt.

R. Subekti, Hukum Perjanjian, Bina Cipta, Bandung, 1987. Aneka Perjanjian, PT. Citra Aditya Bakti, Bandung, 1995.

S. Nasution, Metode Reaseach (Penelitian Ilmiah), PT. Bumi Aksara, Jakarta, 2006.

Sumardjono, Maria S. W., Kebijakan Pertanahan: Antara Regulasi dan Implementasi, Penerbit Buku Kompas, Jakarta, 2009.

Soerjono Soekanto, Pengantar Penelitian Hukum, UI Press, Jakarta, 2010.

Wicaksono, Panduan Lengkap Membuat Surat-Surat Kuasa, Visimedia, Jakarta, 2009.

Wawancara

Wawancara dengan Pangat Suwarto Analis Hukum Pertanahan Kantor Badan Pertanahan Nasional Kabupaten Magelang pada 25 Agustus 2020

Wawancara dengan Notaris Muhammad Nizam Fanani di Kabupaten Magelang pada 24 Agustus 2020, 08.18

Wawancara dengan Bapak Ladang Kunto Anuraga di Kabupaten Magelang pada 8 Agustus 2020, 10.51

Hasil wawancara dengan Ibu Virgina Rapar di Kabupaten Magelang pada 13 Agustus 2020, 13.46

Hasil wawancara dengan Bapak Dwi Kimtoro di Kabupaten Magelang pada 24 Agustus 2020, 14.10

Hasil wawancara dengan Bapak Funnyarifki di Kabupaten Magelang pada 25 Agustus 2020, 14.40 